\title{
The Impacts of Urban Expansion on Livelihoods of the Surrounding Rural Society: The Case of Tefki Town, Oromia Special Zone Surrounding Finfinne
}

\author{
Gadisa Worku \\ Geography and Environmental Studies at Salale University, Ethiopia \\ Email: gadisaworku98 [AT] gmail.com
}

\begin{abstract}
Urbanization is recently a rising trend seen all over the world, mostly in an upsetting rate in developing countries. Similarly, most towns in Ethiopia are recently becoming expanded towards the adjacent rural societies. The Expansions of these towns were resulted in the consuming and conversion of farm land to urban land uses and affects the agrarian livelihoods. This study is intended to assess the impacts of urban expansion on livelihoods of the society surrounding rural kebeles of Tefki town from the year 2015-2019. Specifically, the study focused on evaluating the effects of town expansion on the farmers (households) in terms of income, the opportunities of the affected households secured from the town expansion and compensation process. Hence, 166 expansion affected households were selected through snowball sampling, and also (5) officials from different institutions were purposively taken for key informant interview while (7) respondents from the affected farmers were selected for interview. Thus, the primary data were collected using questionnaires and interview. Secondary data have been also used to triangulate and supplement the first hand information. The collected data were analyzed by using SPSS version 20. The result showed that Tefki town rapidly expanded during the last five years as a result of population growth and industrialization. This expansion made significant effects on livelihoods of the surrounding farmers. Although they secured access to certain services, it was also brought effects like loss of agricultural land and other assets including grazing land which resulted in change of their livelihoods, and unfair compensation. This expansion has made the households of the surrounding area to lose farm land on which their livelihood used to depend on for long period of time. Every farmer has been made to lose an average of 1 hectare of their owned farm land. The grazing land of the area has been decreased because of to wn expansion, and thus made farmersto lack enough place of grazing for their livestock. On the other side, the compensation was not made on time for the affected farmers. The study also found out that the compensation given to the farmers was not fair, and too inadequate to sustain the livelihoods of the affected households. Therefore, a detailed potential effect assessment study should be carried out by the government and other stakeholders prior to implementing urbanization programs so as to minimize the adverse effects of urban expansion.
\end{abstract}

Keywords--- urban expansion, livelihoods, farmers, compensation

\section{INTRODUCTION}

The process of urban expansion is a world wide phenomenon. It started with the earliest human civilization of Babylonians' (Cemea, 1997 cited in Firew, 2010). This phenomenon is now a rising trend seen all over the world, especially in an alarming rate in developing countries. This makes cities grow both in number and in physical size (Haregewoin, 2005). The overall population growth rates for the world is $1 \%$, while the growth rate for urban areas is nearly double, or $1.8 \%$ and the rate of world urban population will double in 38 years and this growth will be even more rapid in the urban areas of less developed region, averaging $2.3 \%$ peryear and expected to double in 30 years; the population in urban areas in less developed countries will grow from 1.9 billion today to 3.9billion, while in developed countries, the urban population is expected to increase very slowly, from 0.9billion tolbillion in 2030(UN HABITAT, 2001). The process of urban expansion, may involve the expansion size of the physical structure of urban areas and it can result in loss of agricultural land, natural beauties, range lands, parks and sceneries and results in change of livelihoods (Min wuy elet, 2005).

Urbanization and urban growth are considered as a modern way of life bringing economic growth and development; however it is encountered with a number of societal problems, particularly on change of livelihoods (Tegenge, 2000 cited in Adem, 2010).

He also further stated that, urban expansion and industry had close relationship in developed nations which has been synonymous with technological advancement, economic development and social tran sformation that triggered and diffused change and dynamism in the whole socio-cultural conditions of the society and this condition indicated that in the developed countries, urbanization was a fore runner of the rise in living standard and at the same time one of its consequences. Unlike the situation in the developed countries at comparable stages of development, the process of urbanization in the third world countries appears to be more a function of rural pu sh factors than the urban pull factors and 
urban expansion creates many challenges that may be above the ability of the economies of the third world countries including the creation of job opportunities and provision of basic needs for those who migrates to city and urban center (Rakodi, 1997). In Ethiopia, as in several other African countries, urbanization is happening at a new swift rate and the competition for land between agriculture and non-agriculture is becoming intense in the peri-urban and it shows that land acquisition and delivery for urban expansion and development purposes is complete ly state controlled on the rationale that all land belongs to the state and peoples of Ethiopia and local peri-urban landholders or indigenous small farmers are largely vulnerable to lose their land where their livelihood is based upon(FDRE,1995). The ever increasing of urban population and outward movement of urban expansion to the fringe peri-urban areas with diversified motivation of the local urban government has affected the lives of farmer's population and expanding towards the periphery agricultural community and rural land use change in to urban land use as major objective of urban development policy has surfaced quite importantly all over the world particularly in rapidly urbanizing developing countries including Ethiopia(Benhit, 2004).

The development of a nationalurban policy is the key step for reas serting urban space and territoriality by providing an overarching coordinating framework to deal with the most pressing is sues related to rapid urbanization, including slum prevention, regularization and job creation, (UNHABITAT, 2012).

The Ethiopian national urban development policy document is founded on ADLI, Industrial development strategy, federalis $\mathrm{m}$, democratization and civil services reform. It is stated in the document that, the speed extent and focus of urban development is dependent on rural development and vice versa. According to the policy document, the main challenges facing the urban areas in the country are poorly developed social and physical infras tructure; shortage and deterioration of hou sing; lack of recreation areas; inadequate municipal waste management; absence of well integrated urban rural linkages; unbalanced urban growth and weakly developed national and regional urban system(MoUDAC, 2012).

The overall vision of the policy is to en sure the growth and development of Ethiopian urban center is guided by plans and to make the cities and the town competitive centers of integrated and sustainable development that are sufficiently res ponsive to the needs of their inhabitants (MoUDAC, 2012). Therefore, this research was intended to assessing the effect of urbanization on livelihoods of peri urban rural s ociety of surrounding Tefkitown.

\section{STATEMENT OF THE PROBLEM}

The expansion of urbanization may result in the conversion of land from agriculture to urban land use. This indicated, expansion of urban areas is of greater importance because of its strong effect on other land cover classes, such as agricultural lands in particular and forests and others in general which resulted in change of livelihoods of the surrounding society. As a result, problem of rapid urban growth and its consequence on farm land in developing countries have been a serious concern is sue and are more worris ome when there is urban expanded on fertile agricultural land and other socioeconomic implication on peri-urban areas of most cities and resulted for livelihoods change (Adeboyejoet, 2007).

In Ethiopia, commercial farms, road construction and urban expansion have been causing consumption of agricultural land and population displacement and it is resulting to related change of livelihoods particularly, as most private investments have so farconcentrated around the main urban centers, mainly the town surrounding Addis Ababa, the problemof farm land is becoming the primarily concern (Feleke, 1999). Tefki town is one of the towns found in Oromia special zone surrounding Finfinne, which is currently expanding tremendously in terms of population and physical size. The expansion of this town created numerous opportunities as well as challenges for surrounding rural farming communities in general and their farming land in particular (OUPI, 2014).

Although Tefkitown Administration has put in place s ome benefit package like compensation for thoselosing lands, little is known how to minimize the effects of urbanization livelihoods of the surrounding society. This requires an as sessment of the existing social, economic, institutional and org anizational structures and compensation procedures that dealt with people who are affected by the expansion of Tefkitown. Different studies were conducted on this problem, but the majority did not adequately address effect of urban expansion on the surrounding livelihoods. So, this research was intended to fill this gap which particularly focuses on effects of urban expansion on livelihoods of the surrounding rural agricultural society.

\section{RESEARCH DESIGN}

The res earch design for this study was cross sectionalres earch design which applied to acquire relevant data and generate appropriate information. 


\subsection{Research Method and Data collection Instruments}

To address the objectives of the study both qualitative and quantitative data were required. In this case, the data collection ins truments like question naires and interviews were applied. In general, under this method, the most important is sues were; to collect data on economic, social, environmental situation, conflicts over resources particularly farm land due to the expansion of the town over agricultural land and to identify the effects of urbanization livelihoods, trends of urbanization, opportunities obtained and amount of compensation.

\subsection{Data Sources}

The study generated both primary and secondary data. The primary data were obtained through information gathering from a rural hou seholds affected by urban expansion and Key Informants. This data was complemented with secondary data gathered fromrelevant literature and government and non-government reports.

\subsection{Sampling Techniques and Sample Size}

pertaining to sampling method and size, the researcher would purposely select Tefki town from the five urban center of sebeta awas woreda to analyze the effect of urban expansion on livelihoods the surrounding rural agrarian. From rural kebeles surrounding Tefkitown the researcher select two kebeles purposively to analyze the effect of urban expansion on livelihoods of the surrounding rural agrarian kebeles. From these farmers' household heads, the data of farmers affected by urban expansion since the last five years (2015-2019) in the two rural kebeles were not clearly obtained fromthe town's municipality office. Due to these is sues, the researcher would use the snowball sampling methods to select the sample res pondents for undergoing household survey. By doing this; the researcher reached at, 89 respondents were fromganda bure kebele and 77 were from bonde kebele. In addition to this, five (5) individual for Key interview were selected purposively fromoutside the s ampled population. They selected fromtown's mayor, developmental agent, and urban land management. And four (7) hous eholds were purposively selected from the affected farmers for interview.

\subsection{Methods of Data Analysis and Presentation}

The data obtain fromquestionnaires was analyzed quantitatively by descriptive statis tics such as: - frequency, percentage, by using Statistical Packages for Social Science (SPSS) version 20. while the data obtained frominterview, was analyzed qualitatively by narrating their words. . Finally, the data obtained fromquestionnaire were presented in the form of cross tabulation, tables, graphs, pie charts, diagrams and figures. While the data obtained from interview and open ended questionnaires were put in the formof text.

\section{RESULTS AND DISCUSSION:}

\subsection{Respondent's Agricultural Land Loses and their Livelihoods (2015-2019) Due to Urban Expansion}

Urban expansion consumes land in general and change farmer's livelihoods in particular. Although urban expansion brings positive social changes, it als o affects natural resources, particularly land when it is not properly planned and resulted in change of livelihoods. As it is shown on Figure 4.1, the participants involved in the study lost their land in different period as a result of urbanization since 2015 to 2019 which resulted in change of their livelihoods.

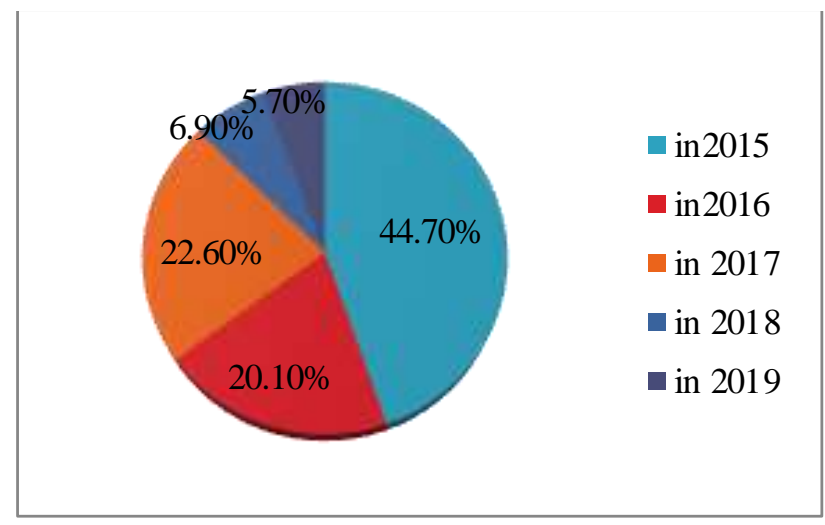

Figure.1: Percentage of Participants who lost their Land during the Years 2015-2019.

According to Figure 1 above, $44.7 \%$ of the respondents have lost their land in 2015 followed by $20.1 \%$ in $2016,22.6 \%$ in $2017,6.9 \%$ in 2018 and $5.7 \%$ in 2019 . In addition to these; theinformation obtained fromthe key informant interviews of the town adminis tration indicated that, majority of the land surrounding the town was occupied by urban expansion 
between the years 2015-2017 while it decreased after 2018 due to economic deficiency encountered by the municipality. This implies that urban expansion in the study area was more in the three consecutive years $(2015,2016$ and2017), which resulted in change of livelihoods of the surrounding society.

\subsection{The Effects of Urban Expansion on Farm Land and Livelihoods}

Urban expansion have effects on farmland by taking the fertile land that the livelihoods of the local people depends on. Before urban expansion majority (40.9\%) of the respondents had land sizes between 2.1-3 hectares while only (3\%) of the res pondents had land sizes below 1 hectare. This implies that nearly half of the respondents (40.9\%) were owned farm land sizes between 2.1-3ha before they lost for urban expansion. While from the total sampled respondents $64.8 \%$ of the respondents were left only with land sizes between 0.5 -2hacters while $10.1 \%$ of the selected respondents were becoming landless after the expansion of the town which directly resulted in change of their previous livelihoods. From this we concluded that, urban expansion towards farmland will decrease the sizes of farm land owned by the respondents before urban expansion and was changed their livelihoods.

\subsection{Change of Job of the Respondents after they lost their Farm Land}

Although respondent households practiced farming all in their life, urban expansions have forced them to consider alternative job opportunities to satisfy their family needs. As result farmers have opted to practice a range of activities including self employment. Consequently, from the total sampled respondents, more than half of the respondents (57.3\%) have changed their job fromagriculture to other activities due to urban expansion. Firew (2010), studied on the horizontal expansion of Hawassa city towards peripheral farm lands explained that; it is fair to say that; although these households had their own effort to employ themselves in different livelihood strategies and alternatives, each of the household's educational background, economic status they had before, the family size they had accommodated, the lack of in stitu tional interventions all limited the output from the newly chosen livelihood. As explained by Teketel (2015), the los s of farmland leads farmers" to change their employment area fromagriculture to semi and/or non-agriculture livelihood activities. From this it concluded that urban expansion is the cause for change of job of the respondents. This can be witnessed from the views of key informants who explained their encounters due to loss of land as indicated below.

I am 59 years old and I was born in the eastern side of ruralkebeles surrounding Tefki town. I was married and have six males and two female children. I had 4.5 hectares offarmland obtained during land redistribution of the Dergue era. I gave three hectares of my farmland to my male children and only one and half hectare was left for me. Because of the expansion of Tefk i town I lost farm land and it is difficult for me to continue my livelihood and my family, I usually rent a quarter hectare of a gricultural land for one thousand and five hundred birr per year. I was not confident to harvest good crops on the rented farm land, becau se crop production is usually based on rainfed. Because oflimitation offarmland to sustain my livelihood and my families, I also rear animals and fatten oxenfor a year to sell them in market on festivity of big holidays like Christmas, Easter and Ethiopian New Year. At the present time, horizontal expansion ofTefki town has consumed my farmland in the east and I was left only with small parcel offarm land. To generate addition income for my family, I was employed as a guard in small factory in Tefki town. This is all happening due to loss ofland due to urban expansion.

\subsection{Opinion on the Compensation Paid for the Land Size they Lost.}

From the total respondents, $80.5 \%$ of the respondents perceived the amount of compensation for the res pective size of land they lost for urban expansion ranges from "dissatisfied" to "strongly dissatisfied", and the remaining $18.87 \%$ respondents and $0.63 \%$ participant responded "just dissatisfied" and "satisfied" respectively. it can also be interpreted that the majority of "dis satisfied" and "strongly dissatis fied" response on the compensation was from those respondents who lost their lands in the first three consecutive years, namely:2015, 2016, and 2017, as compared to the last two consecutive years: 2018, and 2019.

In addition to these; time consideration on compensation was not res pected for them. They also added that; the time gap they promised was so very long that it could not afford livelihood. Addisu Mera (2015), explained that As the results of the compen sation amount and livelihood management shortages the households are facing social, economic, cultural and the livelihood consis tency problembecause of this farmers are going to other area to get farmland by rent or by purchasing to get land specially those who have relatives family relations societies, this shows that livelihood consistency is not given enough concentration by the res ponsible body. Livelihood elements had been affected in one way or in another. On these is sues, Teketel (2015), explained that the reason for the unhappiness on compensation was that, the compensation provided was not enough to sustain their livelihood and replace their income that was previously earned fromagricultural land. The detailed information was obtained fromthe following key informant interview.

I am 55 and I was born in the eastern side of ruralkebele that surrounding Tefkitown. I have married and seven children. My total land in hectare was around 4.5 hectares offarmland and grazing land totally. But at the recent time, I was left only with 2.5 hectares. I got compensation for two hectares by considering cost ofproduction often years. The payment of land was not matched with land size and even it was given in different period. Giving compensation money in different 
period has affected my business negatively because I have neither enough farmland to work on nor the money to plan on for creating job; because I have many families. As a result, I used the paid money to buy farmland on yearly basis from other places. At the early stage Ifailed to educate my children; because it needs many things like school uniform, exercise book, stationerymaterials. After certain time I tried to invest in small shop, but I was not successful in the business. I also tried to fatten up oxen to sell them during big holidays to get reward of higher prices. Even this business is not enough to carry out my family.

\subsection{The Purpose of Farm Land in the Process of Urban Expansion}

Agricultural land is changed to different urban land uses purpose. According to information obtained from the respondents majority of themreplied that their land was used for industry construction. On the one hand theinterview result explained that majority of the land occupied by the first period of urban expansion was used for the purpose of construction. They also told that the other purpose of the town expanding to the rural farm land are to solve the housing problem that arise due to the increasing of the town's population, meanwhile bringing the rural life style into urban life style.

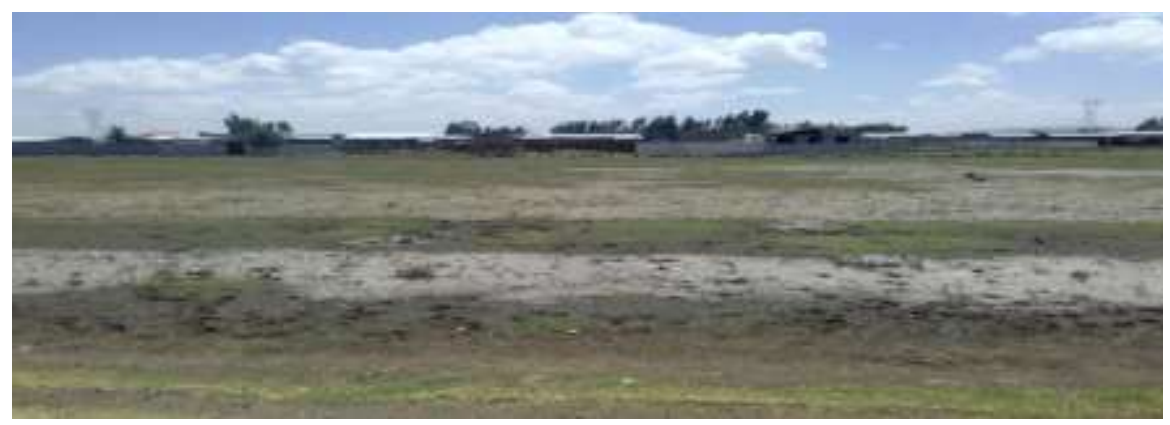

Figure 2: Newly Occupied Areaby Urban Construction

\subsection{The Attitude towards Urbanization}

Farmers affected by urban expansion have different attitude on urban expansion. Accordingly, the respondents were asked to reply their attitude on urban expansion.

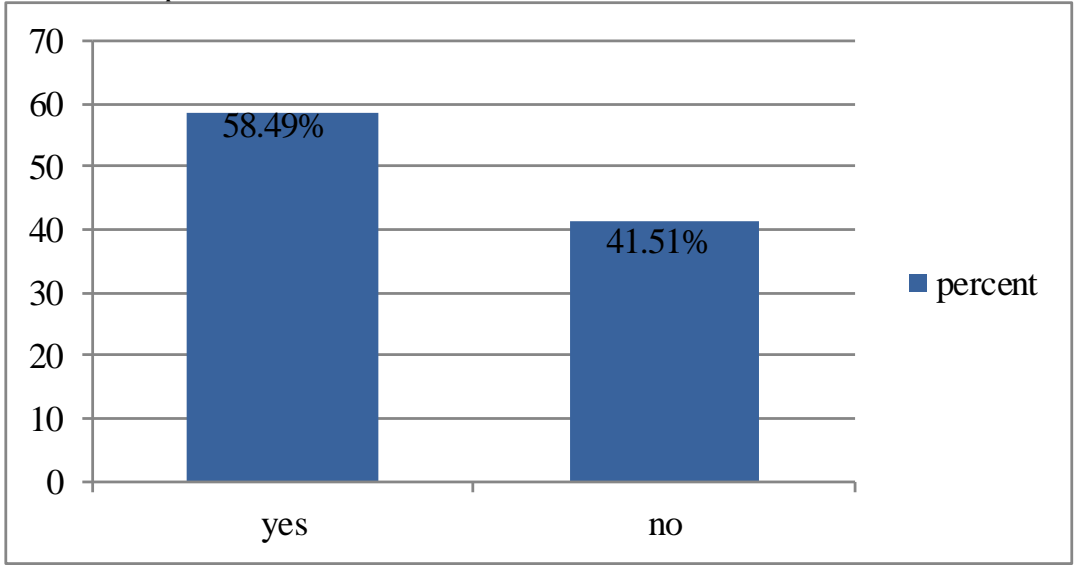

Figure 3: Attitude of the Respondents towards Urban Expansion

The affected farmers were different attitude towards urbanization. Some of themwere encourages while other discourages .As observed from figure 3 above from the total sampled respondents $58.49 \%$ were strongly discourages urban expansion on farm land. While $41.5 \%$ were not. Furthermore, Teketel (2015) explained that to such community as farmers in peripheral areas, urban expansion needs to be not only promis sory and institutionally based, but also it needs to be willingness based and participatory. From this we concluded that urban expansions on the surrounding ruralcommunities were brought negative effects on the surrounding rural farmers.

\subsection{Urban Expansion and Accessing Services}

Although urban expansion had negative consequences on farm land by displacing farmers from the land; it has also brought different services to the town and surrounding community. Accordingly, the rural kebeles surrounding Tefki town was access to the following services since the town expansion. 


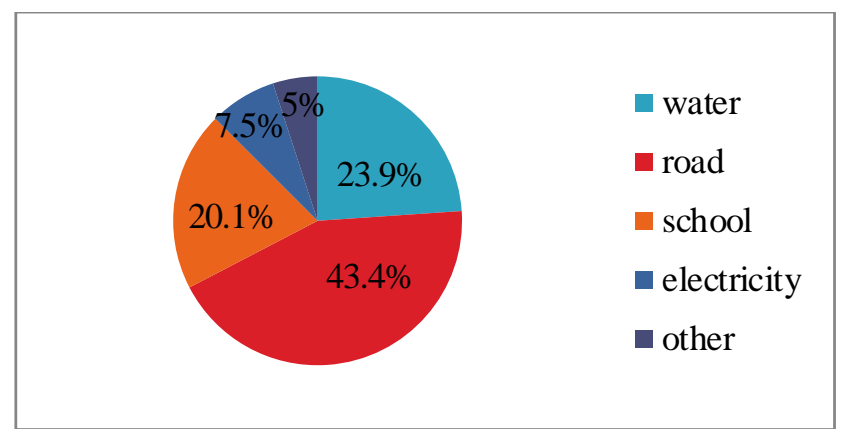

Figure 4: Access to Services due to Urban Expansion

According to figure 4 above, $23.9 \%$ of the res pondents were access to water supply, $43.4 \%$ of them were acces s to road, $20.1 \%$ were able to get school, $7.5 \%$ were obtained electricity services while $5 \%$ were entered other urban bringing services. This implies that, majority of the respondents were access to road while still few of them were access to electricity services. Fromthis one can observe that due to urban expansion different services were accessed than before.

\subsection{Ways of Diversified Income}

Hous eholds are obtained their income in addition to farmland left from urban expansion to increase their livelihoods. The figure below illus trated this idea.

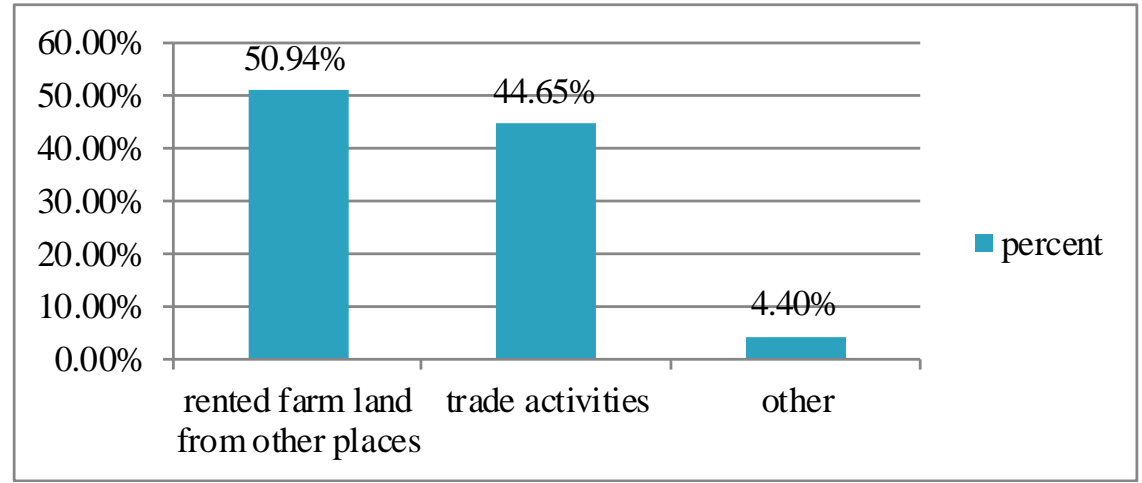

Figure 5: Additional Income Sources of the Res pondents

As tried to label on the above figure 5, from the total of the sampled respondents, majority of the selected sample were obtained additional income from renting agricultural land somewhere else according to their affordability. On the other hand only few res pondents practiced other activities than renting farmland.

\section{CONCLUSION}

The ongoing Urbanization trend is critically affecting the farming community in the study area, by letting them to lose their livelihoods.

As compared to the land size that the farming community in the study area had before they lost some of their lands due to the ong oing Urbanization trend in the locality, every farmer has been made to lose farm land that he/she is economically dependent on which will result in change of their livelihoods.

The amount that, the farming community are receiving as a compensation for the land they lost due to the urban expansion trend in their surrounding has not only been s mall and dis satisfied to all the farmers to compensate what they have lost but also not treating all of themuniformly and als o they do not get thesecompensation on time.

Besides, in relation to the compensation established by the governing bodies at different periods for farmlands taken for urban expansion, most of the respondents argue that what they received as a compensation for the size of land they lost is incomparable and dissatisfied with amount that the government is selling the same land taken from them in auction for urban settlers as residence. The administration bodies bought the land from the farmers in low amount of compensation and re-sell on high amount.

As these farmers are dominantly illiterate to getemployed in other jobs, except daily laborer positions, their chancehave been leading lives worse than what they had before losing their farm lands due to the urban expansion. 
Even though urbanization can have both negative and positive impacts on the lives of people where it takes place, for the farming rural community around Tefki town it does not seem to bring significant change on their livelihoods in the past five years as most of the surrounding people who lost their land as a result reported. Rather, the majority of themreported their livelihood is negatively affected since the urbanization trend started to expand towards their farm land and living area as they reported. As they told, the compensation paid for themwas not s atisfied; they do not getcompensation matched with the sizes of their land, even this compensation was not paid on time. There was lack of policy implementation that treats all affected farmers equally. Not only these, there was als o no other nonprofit organization that help the affected farmers. The affected farmers were only keeping for compensation.

\section{RECOMMENDATIONS ON THE PRACTICAL IMPLICATIONS OF THE STUDY}

The administration bodies of Tefki town and the surrounding rural kebeles have to make use of the findings of this and other similar studies to revisit what sorts of socio-economic influences have their actions on urbanization is causing on both urban and rural groups of people dwelling around, and make corrective meas ures.

Detailed potential impact assessment studies have to be carried out by responsible bodies prior to implementing urbanization programs since their negative impacts could sometimes out weigh their benefits.

Since urbanization could have a potential of s triking economical and political unrest in a society; because agricultural land is highly sensitive to urban expansion towards farmand it consumed farmlands adjacent to it, res ponsible bodies especially agricultural officer should make knowledge-based decisions and actions only depending on empiricalevidences.

As any government has to bes ensitive to its citizen's current and future lives, representatives of the Ethiopian gove rnment at various levels have to treat all portions of the people equally and fairly, since the is sue of land is one of the leading causes of political, social, and economic unrest realities in various corners of the world including Ethiopia. Thus, in effect, the government has to establish well studied laws, rules, and regulations pertaining to its urban and rural land management systems.

\section{ACKNOWLEDGMENT}

First and foremost, my deepest gratitude goes to Almighty God to complete this paper and next to God; I would als o thanks the editorials of this journal who have been contributing their invaluable guidance and constructive comments throughout the article. The way they have been guiding me in the course of the article, was motivating and freedom friendly in a manner that could allow me to use the maximum level of my capacity

\section{REFERENCES}

- (1).Addisu.M,(2015): Effects of Urban Sprawl on the livelihood of suburban agricultural community: the case of Sara Ampol, Yeka Tafo and chorizo Area, Yeka Sub City, Addis AbabaEthiopia

- (2).Adeboyejoet.A, (2007). Predictive Modeling of Urban Expansion and Implication for Livelihood and Sustenance in Peri-urban Areas of Ogbmoso, Nigeria, A paper Presented at $5^{\text {th }}$ African conference at Tanzania, Arusha

- (3).Adem.K, (2010): urban expansion and the neighborhoods: the case of bis hoftu town, a Thesis Submitted to the School of Graduate Studies, Addis Ababa University.

- (4).Benhart .J. E., (2004). Challenges to Asian urbanization in the 21st Century, Volume 75. Moscow@2004 Springer Science + Business Media, Inc. p, 53-57.

- (5).FDRE, (1995): Constitution of the Federal Democratic Republic of Ethiopia proclamation №.1/1995, Negarite Gazette, Addis Ababa, Ethiopia

- (6).Feleke, (1999).impact of urban development on peasant community in Ethiopia: the case of yeka tafo.MA thes is, Addis AbabaUniversity

- (7).Firew. B, (2010): the Impact of Horizontal Urban Expansion on Sub-Urban Agricultural Community Livelihood: the Case of Tabor Sub-City, Hawassa city, SNNPRS, Ethiopia

- (8).Haregewoin. B, (2005): urbanization and urban sprawl M.Sc thesis number 294, Stocklom

- (9).Minwuyelet. M, (2005): City Expansion, Squatter Settlements and Policy Implications in Addis Ababa: The Case of Kolfe Keranio Sub-City, Working papers on population and land usechange in centralEthiopia.

- (10).MoUDAC, (2012): structural plan manual revised edition, Ethiopia.

- (11).Rakodi, C. (1997). Global Forces, Urban Change and Urban Management in Africa, Growth and Management of its Large Cities. Tokyo, the United Nation University Press.

- (12).Teketel F., (2015) .Urban expansion and its effects on peripheral farming communities: the case of hosanna town, MA thesis, Haramaya University

- (13).UN Habitat, (2001): the state of the world cities, United Nations. World urbanization prospects: the 2001 revision. New York: United Nations; 20

- (14).OUPI, (2009). Structural Plan of s ebeta awas woreda Towns, Demographic Profile, Utilities and Social Services Final Report, Addis Ababa, Ethiopia. 